\title{
The Analysis of the Labor Market in Albania
}

\author{
Dr. Zamira SINAJ
}

Department of Business, University of "Ismail Qemali", Vlore, Albania

\begin{abstract}
Albania's economic growth after 1990 was among the highest of all the economies in transition. Economic activity, as measured at the fair value of the gross domestic product (GDP) for the period 1996-2015 grew at an average annual rate of 5.6 percent, despite the shock of 1997 because of the collapse of the pyramid schemes and the contraction in GDP growth in 20014-2015 due to the impact of the economic and financial crisis. Such high levels of economic growth, has been preceded by economic and structural reforms and the expansion of services and construction, spurred by remittances and informal activities.
\end{abstract}

Keywords: budgetary policies, remittances, employment, dual labor markets, informal employment, informality

\section{Introduction}

\subsection{Overview of the economic and social context}

Economic growth was not associated with increased employment opportunities, throughout this period, the level of employment growth remained slow - with significant negative definite peaks in 2009 and 2015. The unemployment rate reached 18.4 percent in year 1999 and its indicator remained in double digits throughout the period 2009-2015. In 2015, it was estimated at 13.2 percent of the workforce

Economic growth was not associated with increased job opportunities, throughout this period, the growth of employment level has remained slow - with considerable negative defined peaks in 2009 and 2015. The unemployment rate reached 18.4 percent in 1999, and its indicator has remained in double digits throughout the period 2009-2014. In 2015, it was estimated at 13.2 percent of the workforce. In 2015, remittances reached 9.2 percent of GDP ( $\$ 1.5$ million), and decreased by $16 \%$ compared to a year ago. The volume of exports grew by 5.9 percent in 2010 to 25.5 percent in 2007 , declined slightly in 2008 (15.6 percent). The volume of imports followed a similar trend, increasing from 9 percent in 2010 to 27.1 percent in 2014, fell to 14.8 per cent in value in 2008. The present value of the deficit increased by 10.5 percent of GDP in 2014 to 14.5 percent in 2015 , reflecting a worsening of the trade deficit and the decline in remittances. Similarly, the trade deficit has risen from 26.5 percent of GDP in 2014 to 27.2 percent in 2015. In 2015, net inflows of capital covered the current account deficit and contributed to the growth of reserves aliens. "The net foreign investment direct investment (FDI) increased by 42 percent, reaching the level of 7 percent of GDP, from 5.9 percent in 2014, with an increasing investment in agriculture. Inflation has fallen from its peak of 42.1 percent in 1997 to 2.5 percent in 2006 . The slight increase in inflation acceleration in 2014 and 2015 (3.1 and 3.5 respectively percent), mainly due to food price growth products. However, inflation has remained within the limits set by the Bank of Albania (2.4 percent).During 2015, the tax administration has made further steps, such as the collection of overall revenue, as well as in administrative reforms. Tax revenues increased from 23.2 percent of GDP in 2014 to 24.3 percent in 2015, as a result of achievements in revenue collection, tax administration and enforcement of a flat tax of 10 percent on income personal tax. revenue collection at local government level, however, remained low. Public spending in 2015 rose to 32.3 percent of GDP, due to the rapid growth of capital spending (8.6 percent of GDP in 2015 compared with 5.8 percent in 2014), which mainly relate to public investment projects.GDP structure underwent significant changes since the early $90 \mathrm{~s}$. The private sector contributes about 80 percent of GDP, while its contribution in employment rose from 81.9 percent in 2013 to 82.1 percent in 2007. During 1996-2015, the industrial sector's contribution to GDP had a stable value of around 10 percent, while that of agriculture halved (from 36.6 percent in 1996 to 18.5 percent in 2015). The services sector recorded the highest contribution to the GDP in 1999 to 60.9 per cent and then sat at 53.2 percent in 2013, stabilizing at around 57 per cent in 2014 and 2015 .Small and medium enterprises (SMEs) play an important role in the economy. By number of employees, the majority of Albanian enterprises 
belonging to the class size small and medium enterprises (SMEs), as shown in the EU 27. About 55 percent of the number of all employees work in companies with fewer than twenty employed. About 91.5 percent of all Albanian enterprises are enterprises micro (with 1-9 employees); 6.2 percent are small enterprises (with 10-49 employees), 1.7 per cent are medium sized enterprises (with 50-249 employees), while the number of large enterprises (250 employees or more) is 0,5 percent of the total. Most enterprises ( 90 per cent) is concentrated in Tirana (51.1 percent of all enterprises) and Durres (39 percent).Upper trend in economic growth coupled with higher wages and pensions brought poverty reduction to 12.4 percent in 2015, from 25.4 percent in 2012. The depth of poverty was reduced during the same period by 5.7 per cent and 2.3 per cent extremism from 1.9 percent in 2012 to 0.7 percent in 2015.

The data on poverty show that the categories of people who face the highest risk of poverty are some of the unemployed, the less educated members of large families and those in rural areas who work in agriculture for their own account. Women heads of households do not present a high risk of falling into poverty than households where the heads are men. This to some extent is due to the fact that their families are part of immigrants who increase income through remittances. The positive trend in poverty reduction is greatly influenced by remittances. Rural areas in the north have been poverty reduction mainly because in these areas the flight of new immigrants, permanent, continues. Compared to the positive impact that remittances have caused living conditions, their impact on productive investments has been, to date, almost negligible. This is particularly true for the agricultural sectorThe Albanian economy has pulled through the global economic crisis quite well. Despite economic downturns in many advanced economies - and consequently reducing Albanian exports and remittances - GDP is estimated to have increased 2.8 percent in 2016. Inflation has remained within the target, while both exports and remittances have started to improve. Albanian government stimulus package has served as an incentive for automatic stabilizers. Monetary policy has contributed to reducing interest rates and injecting liquidity, while the exchange rate of absorption play.Stimulus package, however, increased the fiscal deficit (from 3 per cent in 2014 to 7 per cent of GDP), while government spending increased for large projects of infrastructure (amounting to 70 percent of total investments public) exceeds income. This increase in public debt to 60 percent of GDP, while in 2016, the current account deficit reached 15 percent of GDP, a level that exceeds the planned funding sources for the future. To avoid this trend, the basic objectives of monetary and fiscal policies of Albania for the period 2010-2016 are: i) ensuring macroeconomic stability, ii) maintain the inflation rate at about 3 percent, iii) reduction of public debt to 54 percent of GDP by 2016, and iv) reduction of the current account deficit.

\subsection{Labour Market Analysis}

\subsubsection{Demographic trends}

Albania's demographic profile is characterized by large waves of migration both within and outside the country, leading to the decrease in mortality rates and reproduction. According to the census of 2010, the resident population in Bangladesh is about 3.1 million and its 50.1 percent are females. Institute of Statistics estimates that in the span of a decade, more than a fifth of the Albanian population (about 700,000 people) fled the country in search of better opportunities, mainly in Greece and Italy. During the past few years in Albania have started to notice the wave of returning migrants. Details Ministry of Interior of 2015 speak for more than 47,000 returnees in Albania.



Figure 1.1 Projected number of children, adults and the elderly in the total population

Source: United Nations projections for Albania, http://esa.un.org/unpp 
The age structure has changed significantly over the past decade, although Albania remains a country with the population of younger age in Europe (Figure 2.1). Percentage of children under 15 years, which has been declining since 1990, will continue to shrink significantly both in absolute values, as well as in relation to the total population. Percentage of population over age 65 is growing faster than the rest of the adult population. The percentage of elderly people to the total population will double by the end of 2035 (from 9.7 to 17.8 percent). The percentage of youth aged 15-24 is projected to decrease from 19.1 percent currently to 13.3 percent in 2035 . The decrease dependency ratio for children (34 in 2017, compared with 53 in 1990) and increase that of the old-age dependency (14.4 in 2017 compared with 8.6 in 1990) will have an impact on the labor supply in 2050.Albanian population remains largely rural, with a number of residents in rural areas that constitute 55 percent of the total (Figure 2.2).

Figure 1.2: Changes in rural and urban population from 1979 to 2008 (in percentage)

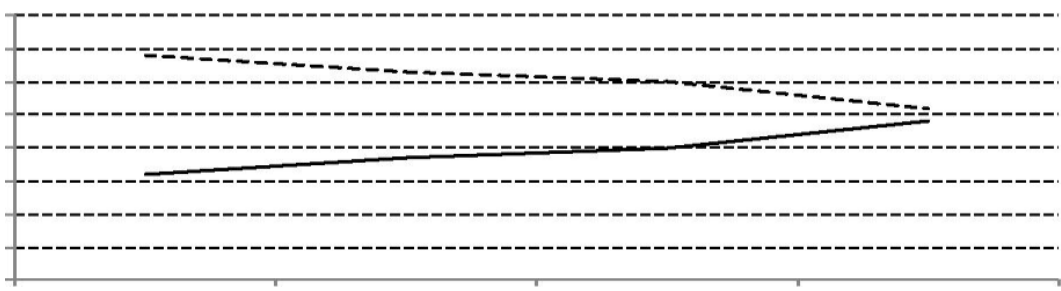

Source: INSTAT, Albania in Figures 2015 Along with the transformation of the economy, Albania experienced the highest migration flows, particularly from the North to the capital and in the coastal areas. There are three main migration patterns arising from the data of the census. The first involves internal migration mainly affects poor areas and remote North-Eastern (Tropoje, Kukes, Mirdita, Puka and Debar). Internal migrants are typically young workers unemployed or underemployed in agriculture. The second model affects districts that have as substantial internal migration and, at the same time and are facing high rates of international migration (Tirana, Durres, Vlore, Fier, Shkodra and Korca). Finally,international migration and internal migration pattern is negligible in districts of southern Albania (Saranda, Delvina and Devoll). These models describe a possible scenario two-step with migrants from northern Albania going first in the rich coastal area or in Tirana, to accumulate sufficient resources to allow them to undertake international migration.Spatial poverty map confirms that the main motivation for people to migrate is directly connected with their work and living conditions and the severity of poverty becoming key determinants. Although regional differences in poverty rates has narrowed significantly in the period 20102015, the north-eastern part of the country remains a higher incidence of poverty estimated 26.6 percent compared with 10.7 percent in the center of the country and 13 percent in coastal regions (Table 2.1). About 21.0 percent of Albanians poor are concentrated in the north-east of the country, although recent measurements show that only 11.0 percent of the country's poor population lives in these areas.

\subsubsection{Trends in Education}

In the period 2010-2015 the rate of education for the Albanian population aged 15 and over was 99.0 percent. In the same period the education of young people was 99.5 per cent ( 99.0 per cent for young men and 100.0 per cent for young women). In the period 2010-2015, the net enrollment ratio in primary education was 93.5 percent (94.0 percent for boys and 93.0 percent for girls). The dropout rate in basic education (grades 1-4) in the 2014-2015 academic year was 0.89 percent and 0.94 percent for 9 -year education.Net enrollment ratio in secondary education rose from 50 percent in the 2017-2019 school year at 58.06 per cent in 2014-2015, while the rate of transfer of primary education (grade 8 ) to secondary education (grades and 9) increased in the same period by 4.3 percentage points. Despite these advances, however, more than 13.5 per cent of young people (15-19) are not in education or training in 2016. Approximately 83.7 percent of students enrolled in secondary education four-year overall (51.2 percent girls), while only 16.3 per cent enroll in vocational schools (35.0 percent girls).

In the 2014-2015 academic year the number of students who continued higher education rose by 4.6 percent. Of the total number of students enrolled in higher education, 57.5 percent are young women.

University graduation rate, however, has declined slightly, from 11.9 percent of students enrolled in academic year 20162018 to 10.1 percent in 2014-2015. The number of individuals educated workforce decreased from 1990. In 2015, less than a third of young people aged 15 to 29 had completed secondary education. Completion rates of higher education have 
remained roughly the same by age group. In the same year the bulk of the working age population (58.4 percent) had primary education; More than a third (32.6 percent) had completed secondary education and 9.0 percent had higher education. In a largely these statistics reflect the fact that Albania is close 85.0 percent of agricultural vocational schools after the failure of communism. As a result, enrollment in vocational / technical declined from 70.0 percent of the overall total enrollment in secondary education in 1998 to 16.0 percent in 2015. In 2010, Albanian students were scoring the second lowest among the countries pjsëmarrëse in the OECD's Programme for International Student Assessment (PISA). In assessing the degree of education about 91.0 percent of Albanian youth aged 15 resulted under level 3 , in contrast to 40.0 percent of young people 15 years of the EU and in contrast to less than the 50.0 per cent of the new members of the EU ( Figure 2.4).

Figure 2.1: The rate of students tested below the 3 (PISA 2010)

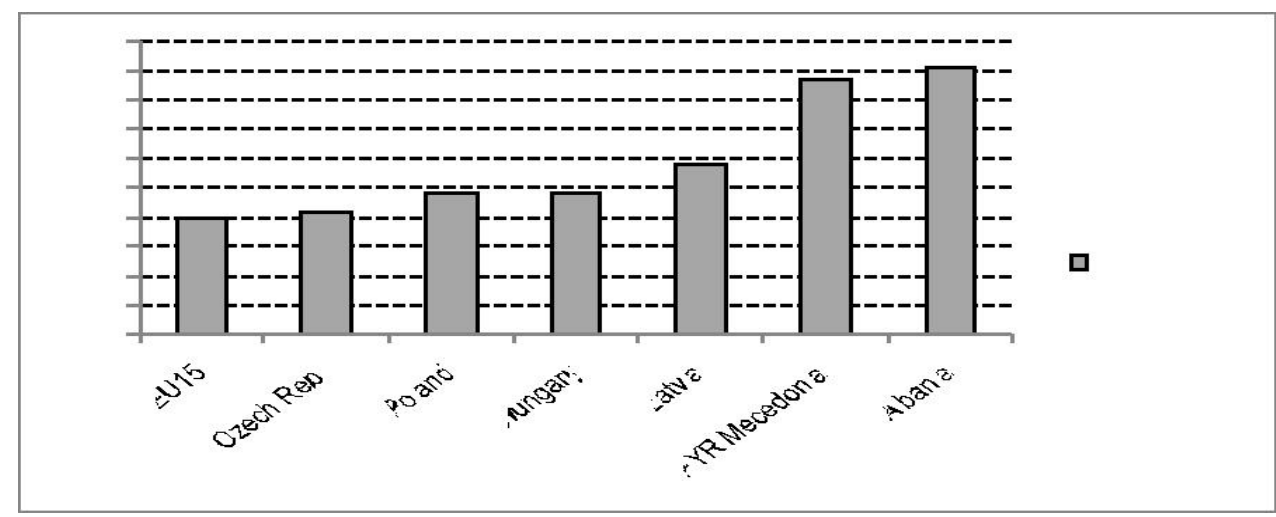

Source: World Bank

\subsubsection{Labor market}

Since 2014, the main source of labor market statistics in Albania Force Survey (LFS). For years before 2014, the labor market data are derived both from Measurement Study of Living Standards (LSMS) and by resources administrative. The analysis in general and the labor market it to young people given in the following chapters is based on data derived from AFP, unless otherwise noted. In the 1990s trends of declining participation and employment rates continued in 2014. Despite the strong growth of GDP in real terms, the unemployment rate remained in double digits throughout the period. In 2015 the unemployment rate for the working age population (15-64 years) was 13.2 percent. Figure 2.5 below shows the total figures of the labor market for the period 2010-2015. One of the main features of the Albanian labor market is a vast difference between women and men in the labor market. Participation of women in the workforce - despite the growth trend since 2010 is about 20 percentage points lower than that of men ( 52.9 percent for women and 72.4 percent for men).Also the employment rate of women is considered lower than that of men ( 45.6 percent and 63.3 percent, respectively). Another key feature of the Albanian labor market is the high share of discouraged workers, which in 2015 accounted for 16.1 percent of all people passive. In the same year, about 73.2 percent of all discouraged workers were women. The structure of employment shows that the work in the private agricultural sector peaked in 2011 with 71.2 percent of total employment decreased to 43.4 percent in 2015. Preliminary 2016 data show declining public sector employment (nearly a percentage point)and in the private sector, non-agricultural sector (-13.5 percentage points) and an increase in private sector, agriculture (14.3 percent). In 2015, the share of women employed in agriculture was well above that of men (57.6 percent and 42.4 percent, respectively).Employment structure by economic activities, as expected, shows that almost 45.0 per cent of workers are employed in agriculture, forestry and fishing sector, 11.7 percent in trade, 7.1 percent in manufacturing and 8.4 percent in the sector construction.

\subsubsection{Youth participation in the labor force}

The labor market of young people is characterized by a relatively participation and a low employment rate and high 
unemployment rate. In 2008 , the youth labor force represented a cross 41.6 percent of the population aged 15 to 29 years, as compared to the national average of 62.1 percent.

The low level of participation of young people is mainly due to school attendance (40.0 percent of young population is in education or training) and because of low participation of young women (35.6 percent).

Despite strong economic growth experienced during the decade 1998-2015, employment growth remained negative until 2014. The employment population ratio fell from 57.0 percent in 1998 to 48.7 percent in 2013. The first study of Force (2014) marked an employment population ratio of 56.4 percent which declined to 53.9 percent in 2015. This level compares unfavorably with the average of the EU27 employment rate of 65.4 percent. In the period 1996-2015 as labor and employment they have been growing at a slower rate than the growth of the working age population. Ivendeve job creation in the private sector - despite its doubling in the period 1996-2015 - was not sufficient to compensate for losses in the public sector ( 30.0 percent) and employment in agriculture ( 28.0 percent).

\begin{tabular}{|c|c|c|c|c|c|c|}
\hline & & & Bujgësi & Industri & Shërbime & Totali \\
\hline $\mathrm{Pa}$ arsim & & & 0.1 & 0.2 & 0.0 & 0.4 \\
\hline Arsim fillor (1-4) & & & 1.3 & 0.6 & 0.5 & 2.4 \\
\hline 8/9 vjet shkollë & & & 36.9 & 10.8 & 8.1 & 55.9 \\
\hline $\begin{array}{l}\text { Arsim } \\
\text { (profesional) }\end{array}$ & mesëm & & 1.8 & 0.5 & 1.9 & 4.2 \\
\hline $\begin{array}{l}\text { Arsim i } \\
\text { përgjithshëm) }\end{array}$ & mesëm & (I & 6.7 & 4.7 & 10.6 & 22.1 \\
\hline $\begin{array}{l}\text { Arsim } \\
\text { Universitet }\end{array}$ & lartë & 1 & 0.3 & 1.2 & 13.5 & 15.0 \\
\hline Total & & & 47.23 & 18.04 & 34.74 & 100.00 \\
\hline
\end{tabular}

\section{Source: INSTAT,}

IN 2015, the employment of young people from 15 to 29 was 31.3 percent, 6 percentage points lower than the rate registered in the EU27 for youth 15-24 (37.2 percent). The disadvantage relative labor market of young women compared to that of young Albanians reflects that employees working age: 27.2 per cent of young women were employed in 2015 (35.9 per cent for young men) compared with 54.1 percent of women increased (76.5 percent of males increased). Ulta scales of employment for women show mundëistë limited to combine job responsibilities relative, but also do doubts rise to discriminatory practices in the labor market.

IN 2015 Around 42.0 per cent of young workers were employed in non-agricultural private sector, young people more than twice compared with young women (respectively 55.0 per cent and 27.0përqind). However, most young people are employed in the private agricultural sector (47.0 per cent of all youth employment), young women more than young men (60.0 percent and 37.0 percent, respectively). NE 2015 on 58.0 percent of all employees youngsters had low education level (compulsory education wound-Time Low), 25.0 percent had secondary education and 15.0 per cent of higher education or more. (Table 2.4). Young workers with low education level prevailing in the agricultural sector, while youth education Higher secondary and work mainly in the service sector. About 43.3 percent of the new employees acquire a page (33.7 percent for males and 51.2 percent for men). The rate of all young people in employment, self employment is 13.0 per cent (10.2 per cent 15.4 per cent women AND men) compared with 34.5 percent for adults.

Table 3.1: Young people employed by status and education level, percentage

employed $\begin{array}{lll}\text { self- } \\ \text { employed }\end{array}$




\begin{tabular}{lllll} 
& & & & \\
& & & family \\
\hline Withaut & 0.3 & 0.0 & 0.1 & 0.4 \\
education & 0.6 & 0.6 & 1.2 & 2.3 \\
$\begin{array}{l}\text { Primary(1-4) } \\
\text { 8/9 years school }\end{array}$ & 15.9 & 7.1 & 32.8 & 55.8 \\
education & 1.8 & 0.7 & 1.7 & 4.2 \\
$\begin{array}{l}\text { secondary(vociatonal) } \\
\text { Seconda }\end{array}$ & 10.7 & 3.9 & 7.4 & 22.1 \\
education & 13.8 & 0.6 & 0.5 & 15.0 \\
Higher education & 43.3 & 13.0 & 43.7 & 100.0 \\
\hline Total & & & & \\
\hline
\end{tabular}

Source: INSTAT, AFP 2008

Contributing family members representing 43.7 percent (56.1 percent for women and 33.4 for men) compared with 26.3 percent for adults ( 9.8 percent for men and 46.8 percent for women). Table 2.5 below shows the relationship between worker status and level of education. Young people with a low level of education work more as members contributing to the family, while they school up and work more as a salaried employee. Well over half of all employees in Albania are in vulnerable employment ( 57.8 per cent) and more than 40.0 percent had low levels of education. Women are much more at risk of being vulnerable employment compared to their male peers (65.6 percent and 51.4 percent, respectively). Vulnerable employment is part of total employment consisting of self-employed and contributing family members. The labor market of young people reflects the same situation: over 55.0 percent of all new employees are in vulnerable employment ( 65.0 per cent for women and 47.0 percent for men).Almost 47.0 percent of young people are employed as agricultural workers (42.1 percent for adults), 11.2 per cent are employed as service workers and sales and 10.4 percent in handicraft and trade related workers (10.8 percent for adults ).

Figure 3.2: Employment unprotected by gender and age, 2008 (percent)

$$
\text { ㅁ }
$$

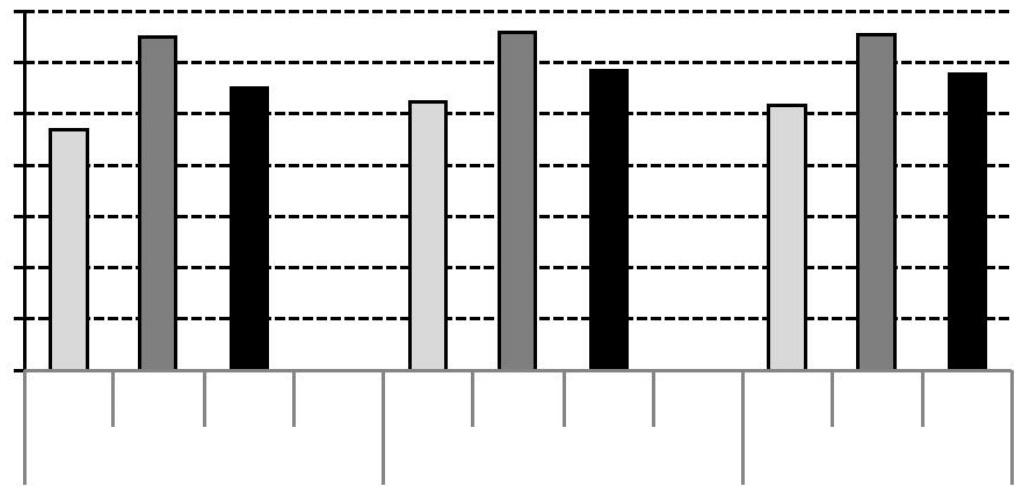

Source: Calculations by AFP 2015

Compared with youth Newest dominate jobs in agriculture (58.6 percent and 37.0 percent, respectively), while the opposite occurs for services / works for sale (14.1 percent for men and 7.7 percent for women) and arts and trade related workers(15.5. Percent for new and 4.4. Per cent for young women). Young women, however, are more likely to be employed in professional jobs compared with their male peers (15.7 percent of women and 4.8 per cent for young men).In 2015 , parttime employment stands for 23.7 percent of total employment, where the number of women employed part time was twice the number of men (33.5 percent and 15.8 percent, respectively). In the same year, the share of young workers working 
part-time was 31.8 percent (41.0 percent for women and 24.1 percent for men).Young people with secondary education are more likely to be employed full time. Among the young people who work part-time, approximately 18.0 percent worked part time because they can not find a full-time job, as compared to 10.4 percent of adult workers). Young women were more likely to work part-time without their choice compared with men (19.7 percent and 16.5 percent, respectively) in a manner similar to what is found in the labor market for adults (11.3 percent for women and 9.7 percent for men).

Table 4.1: Distribution of employment of young people and adults by major occupational groups and gender (in percentage)

\begin{tabular}{|lllll|lll|}
\hline Occupational groups & \multicolumn{3}{c|}{$15-29$} & \multicolumn{3}{c|}{$30-64$} \\
\cline { 2 - 8 } & Man & Women & Total & Man & Women & Total \\
\hline Administrators & 4.1 & 1.9 & 3.1 & 6.1 & 2.3 & 4.4 \\
Professional & 4.8 & 15.7 & 9.8 & 7.6 & 10.4 & 8.9 \\
Technicians and professionals together & 3.4 & 4.5 & 3.9 & 5.3 & 7.6 & 6.3 \\
Employees & 2.1 & 1.8 & 2.0 & 2.0 & 1.9 & 1.9 \\
Service and sales workers & 14.1 & 7.7 & 11.2 & 9.5 & 10.4 & 9.9 \\
Skilled agricultural workers, & & & & & & \\
forestry and fishing & 37.0 & 58.6 & 46.9 & 32.2 & 54.3 & 42.1 \\
Handicrafts and related trade workers & 15.5 & 4.4 & 10.4 & 16.3 & 4.1 & 10.8 \\
Employees of the assembly and use & 4.6 & 1.9 & 3.3 & 9.1 & 1.2 & 5.6 \\
& & & & & & \\
Elementary occupations & 14.4 & 3.6 & 9.5 & 11.8 & 7.8 & 10.0 \\
\hline
\end{tabular}

Temporary employment rate in 2015 was 17.7 per cent, women are likely to be in temporary employment four times less than men (8.6 percent and 23.1 percent, respectively). Almost 14.0 percent of all employees were temporary employees not to choice of their own, where men are likely to be three times more work temporarily without their choice compared with women ( 18.5 percent and 6.0 percent, respectively ). In the same year, about 25.5 percent of all new employees were hired with temporary kontrta where 20.4 percent of this type of contract had no choice. The share of young people in temporary jobs was three times higher than young women (33.7 percent and 10.5 percent, respectively). Similarly, young people are nearly four times more likely than women to work on temporary contracts involuntarily $(27.5$ percent and 7.4 percent, respectively). There is a strong correlation between educational level and temporary employment: young people with compulsory education or less, are twice more likely to be employed in temporary jobs compared to young people with secondary education or higher level.

\subsection{Informal employment}

In Albania, employment in the informal economy is accompanied by low wages, poverty and vulnerability. AFP 2015 data show that approximately 53.0 percent of all employment was in the informal economy. Such figure includes all persons working as contributing family members, all employees whose salary was not paid social contributions and all the selfemployed (in the non-agricultural private sector) with less than five employees

Figure 4.2: Employees without social security contributions paid by gender and age. 




Source: INSTAT, AFP

Employees who have not paid contributions represented a cross 25.0 percent of total employment. Young workers are more exposed to informality than adults (Figure 3.8), men more than women. In 2015 more than 50.0 percent of all young men were informal workers.

Most family members are contributing 30-54 age group (over 60.0 percent), which represent 27.0 percent of young people and workers over 55 years on 11.0 percent. The rate of young workers without social contributions paid, contributing family members and self-employed at a young age without employees - used as a proxy for hiring informal- reached to 70.0 per cent of youth employment.

\subsection{Wages and other working conditions}

In 2015 , wages grew by 8.8 percent in the public sector and 15.1 percent in the private sector. A further increase of 16.0 percent in public sector wages was in 2009 , while the minimum wage rose by 6.0 percent. Measurement Survey of the Living (LSMS) conducted in 2008 marked a wage gap between men and women employed by 17.5 percent, while, on average, 7.6 percent of young people earn less than adult workers. Employees with higher education earn on average 39.0 per cent more than workers with only high school education, while young workers with secondary education have a reward price of 9 percent compared to workers with only primary education. I work 40 hours a week on average, slightly less than the average of hours worked by adults ( 43 hours per week).

\subsection{Unemployment}

Despite positive economic growth and clear growth of the private sector share in GDP, employment creation in the formal economy has not been sufficient to reduce unemployment below a double digit number.

The unemployment rate in Albania fell from 16.4 percent in 2018 to 13.2 percent in 2019. Youth unemployment remains a challenge, as almost 25.0 percent of the youth labor force was unemployed in 2015 (compared with an unemployment rate of 15.3 percent recorded for young people in the EU in 2014). In 2015, the unemployment ratio of youth unemployment rate was 2.5 adults showing that young people are likely two and a half times more likely to be unemployed than adults. Young women are less likely to be unemployed than young men (23.8 percent and 25.5 percent, respectively). Also, young people are more likely than adults to be long-term unemployed ( 12.9 percent compared to 7.4 percent). Contrary to what happens in the labor market of adults - where women are exposed to long-term unemployment than men (8.6 percent and 6.4 percent, respectively) - young men are more likely to be long-term unemployed compared with peers their female (14.1 percent and 11.3 percent, respectively).

The highest incidence of unemployment is found among young people with low levels of education. Among the young unemployed, 51.0 per cent on compulsory education, 40.0 percent have completed secondary education and 8.5 percent are university graduates. Among young people with secondary education graduates of general high school are more likely to be unemployed compared to graduates of vocational schools ( 35.0 and 5.0 percent, respectively). The data collected by 
the National Employment Service (NES) confirm the link between educational attainment and labor market performance: over 53 percentof all registered unemployed have only compulsory education, 31.0

\section{CONCLUSIONS}

1.Analysis of dual employment market in Albania showed that employment in the informal economy is accompanied by low wages, poverty and vulnerability. The fact that a large part of the informal workers are poor, and vice versa, supports the view that between poverty and informality has a mutual respect.

2.Poverty includes all households that are below a certain income line, while informality in turn includes the highest percentage of employees with low incomes. In Albania's case, the existence of a segmented labor market and clear evidence that informal jobs offer low-income, show that informality is one of the causes of poverty

3.As and tax evasion brings reduction in economic and social welfare, as costs for goods and services relevant public will be lower and will influence the further impoverishment of the areas that have an urgent need for investment such as infrastructure, hospitals, schools, universities or continuous supply of energy and water

4.For a country like Albania where unemployment is high and wages are low, due to supply excess and limited demand for labor, fiscal reforms such as the introduction of the flat tax on income or reduction of social security coupled with the determination of wages reference will be in a position the most disadvantaged individuals who are their only source of income wages and businesses operating in informality which are more labor-intensive force

\section{References}

[1] Center for the Study of Democracy, 2003, The informal economy in the EU accession countries: Size, Scope, Trends and Challenges to the Process of EU Enlargement

[2] Alexandre Marc and Zeynep Kudatgobilik, 2013, Poverty and Informality in Southeast Europe

[3] Jan-Peter Olters, Ekonomia informale në Shqipëri:A përbën ajo një pengesë për zhvillimin ekonomik?

[4] DJLMA, 2008, Mbrojtja sociale në Shqipëri,

[5] Banka Boterore, 2014, Shqipëria, rishikim i sistemit të sigurimeve shoqerore. Raport Nr. 37594-AL

[6] Fields, G. (1980), "Varfëria, Pabarazia dhe Zhvillimi”, Cambrigde University Press, New York

[7] Friedrich Schneider, July 2015, "Shadow Economies and Corruption all over the World: New Estimates for 145 Countries".

[8] Klarita Gërxhani, January 2003, "Tax Evasion in Transition: Outcome of an Institutional Clash?- Testing Feige's Conjecture in Albania".

[9] OECD, IMF, ILO and CISSTAT, 2012, "Measuring the Non-Observed Economy;

[10] Handbook".

[11] Friedrich Schneider And Robert Klinglmair, "Shadow Economies Around The World: What Do We Know?". 